\title{
Biomass-Derived Adsorbents for Dye and Heavy Metal Removal from Wastewater
}

\author{
Kashir Ali $\left(\mathbb{D},{ }^{1}\right.$ Muhammad Ussama Javaid $\left(\mathbb{D},{ }^{1}\right.$ Zaman Ali $\mathbb{D}^{1}{ }^{1}$ \\ and Muhammad Junaid Zaghum $\left(^{2}\right.$ \\ ${ }^{1}$ Institute of Soil and Environmental Sciences, University of Agriculture, Faisalabad 38600, Pakistan \\ ${ }^{2}$ Laboratory of Photosynthesis and Environmental Biology, CAS Center for Excellence in Molecular Plant Sciences, Institute of Plant \\ Physiology and Ecology, Chinese Academy of Sciences, 200032 Shanghai, China
}

Correspondence should be addressed to Kashir Ali; kashirali28@gmail.com

Received 22 August 2021; Revised 28 September 2021; Accepted 12 October 2021; Published 29 October 2021

Academic Editor: Selvaraju Narayanasamy

Copyright (c) 2021 Kashir Ali et al. This is an open access article distributed under the Creative Commons Attribution License, which permits unrestricted use, distribution, and reproduction in any medium, provided the original work is properly cited.

\begin{abstract}
Wastewater has a high concentration of dyes and heavy metals, which are the two most significant contaminants. Due to their high toxicity and vulnerability, they possess a potential threat to human health as well as the ecosystem. There are many ways to eliminate these pollutants from water but adsorption has attained much interest because of its low cost, easy application, and no secondary pollutants. Biomass is considered an ecological burden and a reason for the reduction in the earth's carrying capacity. These materials may be used as cost-effective adsorbents to remove dyes and heavy metals from wastewater. This paper highlights recent advances made in dye and heavy metal adsorption in the last 10 years. The prime focus of this review paper is on the direct application of these biomasses without any chemical or physical alteration. The removal efficiencies and adsorption capabilities of different biomass-derived adsorbents for the removal of dyes and heavy metals from wastewater are summarised in this study. Additionally, the adsorption mechanisms underlying the removal of dyes and heavy metals using biomass-derived adsorbents have been discussed, with a focus on two kinetic models: pseudofirst-order and pseudosecondorder. Furthermore, the Langmuir and Freundlich isotherms were utilised to verify the experimental findings and to quantify the amount and degree of adsorption favorability. Based on what has been covered in the literature, the conclusion has been drawn. The future research needs are proposed in the area of biomass-derived adsorbent development, their modification for improved efficiencies, and application on large-scale wastewater treatment plants.
\end{abstract}

\section{Introduction}

Covering more than $70 \%$ of the Earth's surface, water is the major and most important source for the survival of this planet. Without a doubt, water is the most valuable resource among all natural resources, and for the proper functioning of Earth's ecosystem, it is a vital component. In the previous 20 to 30 years, water quality has severely degraded around the world. The major cause of its deterioration is anthropogenic activities. These major anthropogenic activities include but are not limited to the rise in the number of people, industrialisation, urbanisation that was unplanned, and natural resources being used excessively. Water from industries or even natural waters are being contaminated by harmful and toxic or sometimes carcinogenic contaminants which are a major cause of ecological disequilibrium and causing public health issues [1]. The most prominent sources of these pollutants are the release of unprocessed sanitary water and hazardous industrial wastewater, industrial wastewater dumping, and agricultural runoff.

Among these pollutants, heavy metals and dyes are most commonly present in the wastewater and due to their toxicity and nonbiodegradability; these are extremely harmful and difficult to remove. Heavy metal pollution is present in wastewater from many industries such as tanneries, batteries, electroplating, paints, metal refining, fertilisers, and pesticides. [2]. Heavy metals can pose a serious threat to the environment and humans because of their persistency in the environment, nonbiodegradability, and accumulation tendency [3]. These heavy metals include $\mathrm{Hg}^{1+}, \mathrm{Zn}^{2+}, \mathrm{Cr}^{3+}$, 
$\mathrm{Cr}^{6+}, \mathrm{Co}^{2+}, \mathrm{Cu}^{2+}, \mathrm{Ni}^{2+}$, and $\mathrm{Pb}^{2+}$ are categorized as toxic [4]. Because heavy metals do not disintegrate in the environment, their buildup in wastewater might lead to their relocation into water and food meant for human consumption in the long run [5]. The selected parameters limit for different heavy metals in wastewater discharge as per [6] are described in Table 1.

Dyes are being extensively used as a color reagent in industries like textiles, plastic, paper, rubber, food, and cosmetics. As a result, these dyes are left as a major waste in these industries. These are visible in the wastewater even when present at very trace concentrations because of their coloring properties. They are hazardous and sometimes pose extremely lethal effects for example allergenic, carcinogenic, and mutagenic on human as well as on aquatic life. Many organic dyes affect the food chain as well as human and aquatic life and also cause ecological problems $[7,8]$. Malachite green, popular cotton, and silk dyeing chemical have been discovered to be extremely cytotoxic in mammalian cells and to promote liver tumor growth [9]. It is owing to their chemical structure that dyes are resistant to fading in the presence of light, water, and numerous chemicals, making them difficult to remove once released into the water system $[10,11]$. This is a severe environmental problem, prompting scientists to work on new technologies that will allow harmful materials to be removed from polluted environmental sources.

Numerous methods for removing these contaminants from wastewater have been proposed with varying degrees of success, including oxidation, coagulation, chemical precipitation, ion exchange, solvent extraction, membrane separation, reverse osmosis, and adsorption. Many of these methods, however, have disadvantages, including high operating and maintenance costs, the generation of toxic sludge, and a complicated treatment procedure. Adsorption is one of the most effective removal techniques and has garnered much interest due to its simplicity and low susceptibility to hazardous pollutants such as dyes and heavy metals [12]. Adsorption is a mass transfer process in which metal ions are transported from the aqueous solution to the surface of the sorbent, where they are physically or chemically bonded $[13,14]$. All adsorption processes need a solid-liquid equilibrium and mass transfer rates.

Many locally existing materials are being utilised as adsorbents for the exclusion of dyes and heavy metals from wastewater. Low-cost adsorbents like agricultural wastes, natural materials, and industrial products are found to be very effective and encouraging for the heavy metals and dyes removal from wastewater because of their low cost, selective sorption, no sludge production, metal recovery, and high efficiency. Several biomasses such as waste tea, peat moss, rice husk, coconut shells, and sawdust are being utilised as adsorbents. But these studies have not yet been summarised, primarily focusing on the direct application of these adsorbents without any chemical or physical alteration. The ability to utilise such materials as adsorbents without undergoing extensive and costly pretreatments makes them an appealing alternative to traditional adsorbents. They also have the benefit of being immediately available and not requiring regener- ation; therefore, this review focuses on these adsorbents and their efficiency as well as isotherm and kinetic model studies for their ability to effectively eliminate dyes and heavy metals from the wastewater.

\section{Adsorption of Dyes and Heavy Metals by Biomass-Derived Adsorbents}

Biomass-derived materials are plentiful, inexpensive, and have little or no economic worth. Despite all these things, they are present in larger quantities and possess many problems for handling and disposal [15]. When compared to other dye removal techniques, dye effluents treated by adsorption produced better quality treated water. Groundwater, lakes, wetlands, and rivers are all important sources of freshwater for human existence and economic well-being yet they are often contaminated by chemicals released by industry. A long-standing human obsession with freshwater has led us to ignore the equally important advantages of water that leftovers in water courses support healthy freshwater ecosystems. As a result of diverse industries, heavy metals are released into freshwaters where they are easily absorbed by fish and marine creatures. Small quantities of heavy metals can be hazardous because they undergo bioconcentration in the human body. For example, the hexavalent $\mathrm{Cr}^{6+}$ ion is the most bioavailable and hence the most hazardous type of chromium.

2.1. Adsorption of Dyes. Rice husk is low-cost agricultural waste biomass that is readily available. Rice husk is made up of silica, cellulose, hemicellulose, and lignin, among other things. Abbas [16] studied the capacity of rice husk on the adsorption of 4 different kinds of dyes (i.e., methylene blue, brilliant green, Congo red, and crystal violet) from wastewater. The batch experiments were conducted based on initial concentration, absorbance material, packing height, $\mathrm{pH}$, feed flow rate, treatment time, and feed temperature. The results indicated that brilliant green, crystal violet, Congo red, and methylene blue dyes had the highest removal efficacy at 95.81, 96.62, 93.44, and 96.35 percent, respectively. Efficiencies declined as initial concentration and flow rate increased but improved when bed height and feeding temperature increased. The removal efficiencies of brilliant green, methylene blue, and crystal violet dyes increased as the $\mathrm{pH}$ of the solution rose, while the removal efficiencies of Congo red dye dropped as the $\mathrm{pH}$ of the solution increased [16].

In a batch adsorption process, rice husk was utilised to remove Malachite green dye from the aqueous solution [17]. Adsorption experiments were conducted to determine the effect of solution $\mathrm{pH}$, contact time, temperature, and initial dye concentration on adsorption. The $\mathrm{pH}$ of the medium was shown to have a significant effect on adsorption. The equilibrium adsorption findings coincide well with those predicted by the Freundlich isotherm model. Adsorption kinetics followed a pseudosecond-order model, with the rate constant rising with increasing wastewater concentration, implying that adsorption is endothermic. Additionally, rice husk was utilised to remove the dye methylene blue (MB) from wastewater. Batch studies were 
TABLE 1: Heavy metal limits in wastewater as per ZDHC wastewater guidelines [6].

\begin{tabular}{lcccc}
\hline Sr. \# & Heavy metal & Foundational $(\mathrm{mg} / \mathrm{L})$ & Progressive $(\mathrm{mg} / \mathrm{L})$ & Aspirational $(\mathrm{mg} / \mathrm{L})$ \\
\hline 1 & Cadmium & 0.1 & 0.05 & 0.01 \\
2 & Chromium (trivalent and hexavalent) & 0.2 & 0.1 & 0.05 \\
3 & Copper & 1.0 & 0.5 & 0.25 \\
4 & Lead & 0.1 & 0.05 & 0.01 \\
5 & Mercury & 0.01 & 0.005 & 0.001 \\
6 & Cobalt & 1.0 & 0.5 & 0.25 \\
7 & Nickel & 0.2 & 0.1 & 0.05 \\
\hline
\end{tabular}

conducted to determine the effect of various factors. At neutral $\mathrm{pH}, \mathrm{MB}$ may be efficiently eliminated. Methylene blue adsorption on rice husk was shown to increase when the temperature was increased. The Langmuir and Freundlich models were fitted to the adsorption data, and it was found that the Freundlich model matched best with the data [18]. Another research conducted by Sivakumar and coworkers on the removal of direct red 23 dye via rice husk. They eliminated direct red 23 dye from the solution using both treated and untreated rice husk. To determine the effect of dye solution concentration and adsorbent quantity on the percentage of direct red 23 removals, solutions of varying dye concentrations were produced and a known amount of adsorbents were added [19].

The adsorption characteristics of the dyes eosin $\mathrm{Y}$ and red $\mathrm{X}$ from a water solution onto the rice husk were investigated [20]. Numerous batch tests were conducted in order to determine the impact of the adsorbent dosage, contact time, initial concentration, and $\mathrm{pH}$ on the output. On rice husk, the adsorption kinetics of two dyes were shown to be compatible with a pseudosecond-order kinetic model. The equilibrium values for eosin $\mathrm{Y}$ and red $\mathrm{X}$ are well-matched by the Freundlich and Langmuir adsorption isotherms, respectively. The removal percentage of dyes was about $93.44 \%$ for red X $\left(q_{e}=32.44 \mathrm{mg} \mathrm{g}^{-1}\right)$ and $90 \%$ for eosin $\mathrm{Y}\left(q_{e}=\right.$ $\left.31.72 \mathrm{mg} \mathrm{g}^{-1}\right)$. In another study, Saroj and coworkers used maize cob, rice husk, and citrus peel-based adsorbents to remove direct blue 199 from an aqueous solution. At a constant temperature of $28^{\circ} \mathrm{C}$, adsorption equilibrium studies were performed by changing the adsorbent dose. The dye's adsorption varied depending on the adsorbent. Langmuir isotherms were used to connect equilibrium adsorption data for all three adsorbents. Kinetic studies showed that 80-90 percent elimination took around 2 hours. The pseudosecond-order rate equation could properly correlate kinetic data for all of the materials investigated [21].

Patil et al. [22] studied the removal of acid yellow 17 on rice husk. Various study parameters were evaluated, and with $0.7 \mathrm{~g}$ of acid yellow 17 in $20 \mathrm{mg} \mathrm{L}^{-1}$ concentrated solutions, the highest color adsorption was $94.34 \%$. The removal was shown to be strongly $\mathrm{pH}$-dependent, with a maximum at $2.0 \mathrm{pH}$. Adsorption isotherms such as the Langmuir and Freundlich isotherms were studied for these adsorption studies. In the adsorption study, the Freundlich isotherm was fitted well with data. The adsorption kinetics of the first- and second-order kinetics were investigated. A second-order reaction provided an excellent match to the adsorption data.

Seed husk of Bengal gram for the removal of Congo red dye via adsorption from an aqueous solution was studied [23]. The impact of contact time, initial concentration, desorption, and $\mathrm{pH}$ was determined. At lower $\mathrm{pH}$ levels, maximum adsorption occurred, and the dye achieved equilibrium after one hour at a concentration of $25 \mathrm{mg} \mathrm{L}^{-1}$. With increased dye concentration, the adsorption percentage dropped to $74 \%$ from $89 \%$, while a lower $\mathrm{pH}$ resulted in 92\% removal efficiency. To assess the equilibrium data, Freundlich and Langmuir isotherms were employed. The greatest adsorption capacity, $41.66 \mathrm{mg} \mathrm{g}^{-1}$, was determined using the Langmuir isotherms. Congo red adsorption was most effective when using a pseudosecond-order kinetics model.

The groundnut shell and sorghum husk were employed as adsorbents for methylene blue (MB) dye adsorption. The effect of several experimental variables on the amount of adsorption was investigated, including contact time and initial dye concentration. The results indicated that raising the dye concentration improved the proportion of $\mathrm{MB}$ dye removed. The Langmuir and Freundlich models were used to depict the equilibrium data. With MB dye, the maximum adsorption capacity was determined to be $7.05 \mathrm{mgg}^{-1}$ for groundnut shells and $15.38 \mathrm{mg} \mathrm{g}^{-1}$ for sorghum husk, respectively. To model the adsorption data, pseudofirst and pseudosecond-order kinetic models were employed. The pseudosecond-order kinetic model was found to be the most accurate for all adsorption processes [24].

Adsorption of tartrazine yellow dye using groundnut shell was evaluated. To determine the quantity of dye adsorbed, many batch tests were conducted [25]. It was found that the adsorption efficiency is enhanced when the dosage, contact time, and operating temperature are increased. Calculated adsorption capacity increased from $0.21 \mathrm{mgg}^{-1}$ to $1.21 \mathrm{mgg}^{-1}$ when the dye concentration increased from 10 to $50 \mathrm{mgg}^{-1}$. Additionally, when the $\mathrm{pH}$ increased from 2.0 to 10 , the dye concentration decreased from $0.22 \mathrm{mg} \mathrm{g}^{-1}$ to $0.20 \mathrm{mg} \mathrm{g}^{-1}$. To assess biosorption effectiveness, Freundlich and Langmuir models were employed. Both isotherms had coefficients of determination $\left(R^{2}\right)$ of 0.9988 and 0.9982, respectively. Pseudofirst-order and pseudosecond-order kinetics were also used to evaluate the experimental results. Additional studies were carried out to determine the adsorption of Congo red dye from an aqueous 
solution on the surfaces of sugarcane bagasse (SB) and bambara groundnut shells (BGS). The researchers looked at the effects of $\mathrm{pH}$, dose, initial concentration, and contact time on the results. The findings indicated a high efficiency of $75 \%$ and $93 \%$ with $4.5 \mathrm{~g}$ of BGS and SB, respectively. Additionally, when the dye loading concentration increased, the percent elimination increased, while it decreased as the $\mathrm{pH}$ of the solution moved up from 4 to 10 [26].

Wheat bran, an inexpensive and environmentally acceptable biosorbent, has been effectively used to remove textile dyes from water solutions. Remazol red F3B (Reactive red 180) as a model textile dye was used [27]. They investigated the impact of contact time, initial concentration, $\mathrm{pH}$, temperature, and adsorbent dosage on the removal process. The optimal conditions were determined to be a contact time of 4 hours, an initial dye concentration of $200 \mathrm{mg} \mathrm{L}^{-1}$, a $\mathrm{pH}$ of 2.0 , an adsorbent dosage of $0.25 \mathrm{~g}$, and a temperature of $20^{\circ} \mathrm{C}$. The adsorption capacity of this dye was determined to be $39.42 \mathrm{mg} \mathrm{g}^{-1}$. The results indicated that adsorption was highest at an acidic $\mathrm{pH}$. By applying these optimum conditions, five other dyes were investigated. The experimental data were also evaluated for Freundlich and Langmuir models, and the results indicated that the Langmuir equation fit best for the adsorption of these dyes [28].

The adsorption of coomassie brilliant blue (CBB) on wheat bran in an aqueous solution was investigated. The adsorption behavior of coomassie brilliant blue on wheat bran by varying the $\mathrm{pH}$, dosage, and contact time were studied. Up to 95.70 percent of the dye was removed from the solution onto the wheat bran under optimal conditions. The Freundlich and Langmuir adsorption isotherms were used to analyse the findings. The Freundlich model has shown to be pretty valid and to promote multilayer adsorption. The maximal capacity of adsorption, $q_{m}$, was determined to be $6.41 \mathrm{mgg}^{-1}$. Unprocessed wheat bran is an economical and efficient adsorbent for removing colors from textile industry effluent [27].

A study conducted by Alzaydien [29] discusses the use of wheat bran (WB) to remove methyl orange (MO) from polluted water. The elimination of MO from aqueous solution onto $\mathrm{WB}$ was studied using variables such as temperature, adsorbent dosage, $\mathrm{pH}$, and contact time. The quantity of dye removed decreased when the adsorbent dosage, temperature, and contact time were increased. $\mathrm{pH} 4.0$ was found to be the optimum for dye adsorption. The data on the adsorption of MO through WB was also used to generate pseudofirst-order and pseudosecond-order models. The findings suggest that using WB as a cheap adsorbent, it is possible to efficiently adsorb $\mathrm{MO}$ from aqueous solutions [29].

Sawdust is one of the most interesting components of agricultural waste; it is used to remove contaminants like dyes and heavy metals from contaminated water. Sawdust is readily accessible since it is waste from sawmills and is sold at a low cost. Furthermore, because sawdust is biodegradable, its disposal as trash should not damage the environment or any of its constituents. The structure of sawdust, as well as its constituents, makes it a research subject for its adsorption process. Akhouairi and colleagues studied the adsorption of eriochrome black $\mathrm{T}$ dye on sawdust. The impact of different operational factors on the adsorption process was studied. Adsorption equilibrium was found to be in accord with the pseudosecond-order equation and the Langmuir model. Thus, at $\mathrm{pH} 4$, the highest amount of EBT dye adsorbed was found to be $40.96 \mathrm{mg}$ EBT per gram of sawdust, which equates to an 80 percent dye removal rate. Furthermore, the effect of several factors on the adsorption of dye, for example, dosage of adsorbent, aqueous phase $\mathrm{pH}$, and dye concentration were investigated. The amount of sawdust adsorb was observed to increase when the aqueous phase $\mathrm{pH}$ was decreased or increased when the amount of sawdust was increased [30].

The possibility of removing Congo red from the effluent using unprocessed sawdust was examined using batch study [31]. The adsorption experiments utilised a variety of adsorbent particle sizes $(90 \mathrm{~m}, 144 \mathrm{~m}$, and $355 \mathrm{~m}), \mathrm{pH}$ values ranging from 5.0 to 11.0 , and adsorbent amounts ranging from 2.0 to $8.0 \mathrm{~g}$. Additionally, depending on the application, the flow rate ranged between 0.3 and $0.7 \mathrm{~mL} \mathrm{~min}^{-1}$. Sawdust that had not been treated was saturated at a lower volume. The following parameters were tested to effectively remove Congo red dye: a constant initial concentration $\left(10 \mathrm{mg} \mathrm{L}^{-1}\right.$ dye solution), a volume of $200.0 \mathrm{~mL}$, a flow velocity of 0.3 milliliters per minute, and a particle size of $90 \mathrm{~m} \mathrm{[31].} \mathrm{The}$ adsorption capability of methylene blue dye from polluted water was investigated using three distinct low-cost adsorbents (banana fiber, sawdust, and coconut fiber). Additional trials were conducted with an initial dosage of $250 \mathrm{mg} \mathrm{L}^{-1}$. Temperature, $\mathrm{pH}$, adsorbent dosage, and contact time were all evaluated, and it was determined that a temperature of $40^{\circ} \mathrm{C}$, a $\mathrm{pH}$ of 7 , and a contact time of 120 minutes were optimal. According to the findings, coconut fiber has a higher capacity for dye binding than the other adsorbents and may show to be an effective adsorbent for the extensive removal of compound dyes from effluents [32].

Hebeish et al. [33] studied sawdust for adsorption of direct red 23 from wastewater solution. Removal experiments were conducted to determine the removal capacity of direct red 23 on sawdust using a variety of agitation times, adsorbate and adsorbent concentrations, and the effect of each on the removal capacity of direct red 23 on sawdust. Freundlich and Langmuir models were utilised in the adsorption studies. In another research, Khattri and Singh also investigated the use of sawdust to eliminate crystal violet dye from wastewater. The feasibility of removing crystal violet using sagaun sawdust was determined by varying agitation time, adsorbent dosage, dye concentration, temperature, and $\mathrm{pH}$. Adsorption effectiveness was shown to be $\mathrm{pH}$-dependent. A greater proportion of dye was removed by decreasing the initial dye concentration and increasing the quantity of adsorbent. A kinetic study showed the dye's gradual adsorption on sawdust [34].

Suganya et al. [35] used sawdust to adsorb methylene blue dye from contaminated solution. Adsorption experimental parameters such as contact time, initial dye concentration, solution $\mathrm{pH}$, and adsorbent dose were optimised via trial and error to achieve the maximum removal of $\mathrm{MB}$ dye from wastewater. To forecast system behavior, experimental 
data were utilised to generate various theoretical models. The optimum conditions for maximal MB dye removal from contaminated solution were found using a $25 \mathrm{mg} \mathrm{L}^{-1}$ initial concentration of $\mathrm{MB}$ dye: the adsorbent dose of $3 \mathrm{gL}^{-1}$, solution $\mathrm{pH}$ of 7.0, contact time of $90 \mathrm{~min}$, and temperature of $30^{\circ} \mathrm{C}$. The pseudosecond-order and Freundlich models match the experimental data well.

To get a better understanding of the adsorption process and the potential of coir pith as biomass for pollution control due to textile dyes, in another study, Khan et al. [36] used coir pith as an adsorbent for the removal of acid yellow 99. According to the findings, $1 \mathrm{~g}$ of coir pith could adsorb $442.13 \mathrm{mg}$ of acid yellow 99 . The removal process was found to be highly $\mathrm{pH}$-dependent, with 2.0 being the optimal value. The Langmuir-Freundlich dual isotherm model is used to describe the process. The potential of removing Malachite green utilising coir pith as an adsorbent derived from coconut husk was explored [37]. Contact time, agitation speed, $\mathrm{pH}$, and particle size are factors in batch adsorption experiments. To fit the equilibrium data, Freundlich and Langmuir isotherms are employed. The data matched the Freundlich model well.

Hamzeh and coworkers examined the removal of acid orange 7 and remazol black 5 by changing the $\mathrm{pH}$, initial dye concentration, dosage, and contact time. Both dyes exhibited their peak absorption capacity at a $\mathrm{pH}$ of 2.5 and a contact time of 120 minutes. The experimental findings were interpreted using a mix of Langmuir and Freundlich models. For both dyes, the isotherms are found to be linear across the full concentration range. The Langmuir model was shown to be the best match for the experimental data, with the greatest values of linear correlation coefficients for AO7 (0.9926) and RB5 (0.9882). The absorption kinetics were studied using pseudofirst- and second-order equations. A pseudosecond-order equation may predict both dyes' absorptions [38].

Pine cone as adsorbent for the adsorption of acid black 26 (AB26), acid green 25 (AG25), and acid blue 7 (AB7) in water solution was studied [39]. The impact of process variables on dye removal was investigated. These included the amount of adsorbent used, the dye concentration, the amount of inorganic anion (salt), $\mathrm{pH}$, and the temperature. The kinetics data were described using the pseudofirst- and pseudosecond-order. Langmuir and Freundlich models were used to investigate equilibrium isotherms. They discovered that the isotherm data from AB26 and AG25 were consistent with Langmuir's model, while the isotherm data from $A B 7$ were consistent with Freundlich's model [39]. Table 2 depicts the removal efficiencies of various biomass-derived adsorbents for the elimination of dyes from wastewater while Table 3 describes the adsorption capacities of several biomass-derived adsorbents for the adsorption of dyes from wastewater.

2.2. Adsorption of Heavy Metals. Coffee husk was examined for its capability to adsorb $\mathrm{Cr}^{6+}$ from contaminated water in an experiment conducted [41]. Researchers at the University of Texas at Austin have studied how well this adsorbent can remove $\mathrm{Cr}^{6+}$ ions from industrial effluent. It was then applied to actual wastewater. Amount of adsorption as a function of $\mathrm{pH}$, contact time, dosage, and initial concentration of adsorbed material was investigated. Ions of $\mathrm{Cr}^{6+}$ can be adsorb well utilising coffee husk within $60 \mathrm{~min}$. The adsorption of $\mathrm{Cr}^{6+}$ ions by this adsorbent at $\mathrm{pH} 2$ was maximum. The optimum conditions were $80 \mathrm{mg} \mathrm{L}^{-1}, 60 \mathrm{~min}$, $2 \mathrm{gL}^{-1}, 200 \mathrm{rpm}$, and $3 \mathrm{gL}^{-1}$, for the initial concentration, time contact, $\mathrm{pH}$, stirring speed, and adsorbent dosage, correspondingly. A study was conducted [42] to examine the use of discarded tea and coffee grounds as low-cost adsorbents for $\mathrm{Cr}^{6+}$, contact time was 180 minutes, the adsorbent dosage was $2 \mathrm{~g}$, the $\mathrm{pH}$ was 2.0 , the temperature was 30-50 degrees, and the speed of the stirring was $30 \mathrm{rpm}$ (250 rpm). A strong correlation value was observed between the Freundlich isotherm and Langmuir model. There was a strong consensus between the pseudosecond-order model values for the adsorption of $\mathrm{Cr}^{6+}$. Data from the experiments showed an absorptive capacity of $87.72 \mathrm{mgg}^{-1}$ of coffee ground and $94.34 \mathrm{mg} \mathrm{g}^{-1}$ of mixed waste tea [42].

In addition, rice husk is a biobased adsorbent substance that may be used to eliminate pollutants from the water. It was found that rice husk, a porous carbon material, may be utilised to remove lead $(\mathrm{Pb})$ and arsenic $(\mathrm{As})$ from water solutions. The removal efficiency under various conditions of contact time (3-90 min), $\mathrm{pH}(3-9)$, and initially adsorbed concentration $(10-100 \mu \mathrm{g} \mathrm{L}-1)$, and adsorbent amount $\left(0.5-6 \mathrm{gL}^{-1}\right)$ by varying the parameters in the adsorption reactions was investigated. Using analysis of variance, the removal efficiency was eventually determined. Optimum conditions enhanced the adsorption efficiency of $\mathrm{As}$ and $\mathrm{Pb}$ in water solutions (up to $85 \%, 97 \%$, respectively) [43].

The possibility of utilising Polish peat from five distinct health sources as a heavy metal adsorbent in industrial effluent from the steel electropolishing process was studied [44]. Testing was done on the materials utilising both laboratory and industrial wastewater. Peat was used to treating model laboratory and industrial effluent with high initial metal concentrations such as $\mathrm{Fe}, \mathrm{Cr}, \mathrm{Ni}$, and $\mathrm{Cu}$. The removal rate for chromium and iron at an initial concentration of $1000 \mathrm{mg} \mathrm{dm}^{-3}$ was 99 percent, whereas nickel and copper were removed at a rate of $66 \%$.

The capacity of several agricultural waste materials, such as almond shells (AS), walnut shells (WS), peanut shells (PS), and coconut shells (CS) to eliminate $\mathrm{Cr}^{6+}$ from water at room temperature and acidic $\mathrm{pH}$ utilising batch mode was studied [45]. While the adsorption of $\mathrm{Cr}^{6+}$ was adequately characterised by Langmuir model, the walnut shell provided higher adsorption yield and maximal monolayer capacity, which was found to be $37.5 \mathrm{mgg}^{-1}$. Removal of $\mathrm{Cr}^{6+}$ follows a pseudosecond-order according to the kinetics model. As well as this, analysis of the materials using FTIR and X-ray diffraction revealed that the adsorbent materials did not experience any change following adsorption. As a result, the type of adsorption was confirmed as physical.

Ogata et al. [46] conducted an experiment in which raw wheat bran (WB) was examined. The study also examined the adsorption of $\mathrm{Pb}^{2+}$ and $\mathrm{Cd}^{2+}$ ions on wheat bran. Equilibrium was achieved in 9 hours for the heavy metal ions, 
TABLE 2: Reported removal efficiencies (\%) of various biomass-derived adsorbents for the removal of different dyes.

\begin{tabular}{|c|c|c|c|}
\hline Material & Dyes & Efficiency (\%) & Reference \\
\hline \multirow{8}{*}{ Rice husk } & Congo red & 93.44 & {$[16]$} \\
\hline & Methylene blue & 95.81 & {$[16]$} \\
\hline & Crystal violet & 96.35 & {$[16]$} \\
\hline & Brilliant green & 96.62 & {$[16]$} \\
\hline & Direct red 23 & 67.5 & [19] \\
\hline & Eosin Y & 90.0 & {$[20]$} \\
\hline & Red X & 93.44 & {$[20]$} \\
\hline & Acid yellow 17 & 94.34 & {$[22]$} \\
\hline Gram seed husk & Congo red & 92.00 & [23] \\
\hline Coconut fiber & Methylene blue & 96.0 & {$[32]$} \\
\hline \multirow{6}{*}{ Sawdust } & Methylene blue & 89.0 & [32] \\
\hline & Eriochrome black $\mathrm{T}$ & 80.0 & {$[30]$} \\
\hline & Congo red & 91.33 & {$[40]$} \\
\hline & Direct red 23 & 93.0 & [33] \\
\hline & Crystal violet & 89.46 & {$[34]$} \\
\hline & Methylene blue & 99.15 & {$[35]$} \\
\hline Banana fiber & Methylene blue & 85.0 & {$[32]$} \\
\hline \multirow{2}{*}{ Groundnut shell } & Tartrazine yellow & 85.2 & [25] \\
\hline & Congo red & 75.0 & {$[26]$} \\
\hline \multirow{2}{*}{ Canola stalks } & Acid orange 7 & $>90.0$ & {$[38]$} \\
\hline & Remazol black 5 & $>90.0$ & {$[38]$} \\
\hline Sugarcane bagasse & Congo red & 93.0 & {$[26]$} \\
\hline Wheat bran & Coomassie brilliant blue & 95.70 & {$[27]$} \\
\hline
\end{tabular}

TABLE 3: Reported adsorption capacities $\left(\mathrm{mg} \mathrm{g}^{-1}\right)$ of various biomass-derived adsorbents for the removal of different dyes.

\begin{tabular}{|c|c|c|c|}
\hline Material & Dyes & $q_{e}\left(\mathrm{mgg}^{-1}\right)$ & Reference \\
\hline \multirow{9}{*}{ Wheat bran } & Remazol red F3B & 39.42 & {$[28]$} \\
\hline & Reactive brilliant orange $3 \mathrm{R}$ & 34.03 & {$[28]$} \\
\hline & Remazol black B & 38.44 & {$[28]$} \\
\hline & Sirius red F3B & 36.03 & {$[28]$} \\
\hline & Telon red $\mathrm{BN}$ & 39.15 & {$[28]$} \\
\hline & Telon yellow $4 \mathrm{R}$ & 37.76 & {$[28]$} \\
\hline & Methyl orange & 19.85 & [29] \\
\hline & Methylene blue & 1400 & {$[18]$} \\
\hline & Direct blue 199 & 8.6 & {$[21]$} \\
\hline Citrus peel & Direct blue 199 & 12.6 & {$[21]$} \\
\hline Corn cob (powder) & Direct blue 199 & 12.7 & {$[21]$} \\
\hline \multirow{2}{*}{ Coir pith } & Malachite green & 41.46 & {$[37]$} \\
\hline & Acid yellow 99 & 442.13 & {$[36]$} \\
\hline Groundnut shell & Methylene blue & 7.052 & {$[24]$} \\
\hline Sorghum husk & Methylene blue & 15.40 & {$[24]$} \\
\hline \multirow{3}{*}{ Pine cone } & Acid black 7 & 37.4 & [39] \\
\hline & Acid green 25 & 43.3 & [39] \\
\hline & Acid blue 26 & 62.9 & [39] \\
\hline
\end{tabular}


TABLE 4: Reported removal efficiencies (\%) of various biomassderived adsorbents for the removal of different heavy metals.

\begin{tabular}{|c|c|c|c|}
\hline Material & Heavy metals & Efficiency (\%) & Reference \\
\hline Coffee husk & $\mathrm{Cr}^{6+}$ & 97.4 & {$[41]$} \\
\hline \multirow{2}{*}{ Rice husk } & $\mathrm{Pb}^{2+}$ & 97 & {$[43]$} \\
\hline & $\mathrm{As}^{5+}$ & 85 & {$[43]$} \\
\hline \multirow{4}{*}{ Polish peat } & $\mathrm{Fe}^{3+}$ & 99 & {$[44]$} \\
\hline & $\mathrm{Cr}^{6+}$ & 99 & {$[44]$} \\
\hline & $\mathrm{Ni}^{2+}$ & 66 & {$[44]$} \\
\hline & $\mathrm{Cu}^{2+}$ & 66 & {$[44]$} \\
\hline Walnut shell & $\mathrm{Cr}^{6+}$ & $>80$ & {$[45]$} \\
\hline Coconut shell & $\mathrm{Cr}^{6+}$ & $>59$ & {$[45]$} \\
\hline Almond shell & $\mathrm{Cr}^{6+}$ & $>35$ & {$[45]$} \\
\hline \multirow{3}{*}{ Groundnut shell } & $\mathrm{Pb}^{2+}$ & 68.2 & {$[49]$} \\
\hline & $\mathrm{Cu}^{2+}$ & 77.8 & [49] \\
\hline & $\mathrm{Cr}^{6+}$ & 87.6 & {$[50]$} \\
\hline \multirow{6}{*}{ Peanut shell } & $\mathrm{Cr}^{6+}$ & $>52$ & {$[45]$} \\
\hline & $\mathrm{Cr}^{6+}$ & 88 & [48] \\
\hline & $\mathrm{Pb}^{2+}$ & 72 & {$[52]$} \\
\hline & $\mathrm{Ni}^{2+}$ & 25.4 & {$[56]$} \\
\hline & $\mathrm{Cu}^{2+}$ & 82 & {$[58]$} \\
\hline & $\mathrm{Cr}^{3+}$ & 89 & {$[58]$} \\
\hline \multirow[t]{2}{*}{ Wheat bran } & $\mathrm{Cr}^{6+}$ & 51 & {$[54]$} \\
\hline & $\mathrm{Pb}^{2+}$ & $>80$ & {$[55]$} \\
\hline \multirow[t]{2}{*}{ Wheat straw } & $\mathrm{Cr}^{6+}$ & $>80$ & {$[55]$} \\
\hline & $\mathrm{Cd}^{2+}$ & $>80$ & {$[55]$} \\
\hline \multirow{3}{*}{ Coir pith } & $\mathrm{Ni}^{2+}$ & 82 & {$[57]$} \\
\hline & $\mathrm{Cu}^{2+}$ & 82 & [57] \\
\hline & $\mathrm{Zn}^{2+}$ & 88 & {$[57]$} \\
\hline
\end{tabular}

and the experimental data were fitted to a pseudosecondorder model. Correlation coefficients greater than 0.975 and 0.884 were found between the quantity of adsorbed ions and the amount of pectin or carboxy groups, respectively. Raw wheat bran (R-WB) was utilised as an adsorbent in an experiment [47]. It was determined that R-WB has certain characteristics. $\mathrm{Pb}^{2+}$ and $\mathrm{Cd}^{2+}$ ions were also tested for adsorption onto R-WB. A pseudosecond-order kinetic model was used to explain the adsorption of cadmium and lead ions on R-WB. Increasing the temperature resulted in a greater quantity of adsorption. The correlation value of the Langmuir equation is 0.996 for $\mathrm{Pb}^{2+}$ ions and 0.999 for $\mathrm{Cd}^{2+}$, whereas the Freundlich equation has a correlation coefficient of 0.993 for $\mathrm{Pb}^{2+}$ and 0.994 for $\mathrm{Cd}^{2+}$.

The biosorption of $\mathrm{Cr}^{6+}$ ions from water solution using a peanut shell (PNS) biosorbent in a batch method was investigated [48]. These factors included the initial concentrations (20-60 $\left.\mathrm{mg} \mathrm{L}^{-1}\right), \mathrm{pH}$ (2 to 7 ), and contact time (6 hours) as well as adsorbent dose (0.2-1.0 g) and temperature (293$313 \mathrm{~K}$ ) of the $\mathrm{Cr}$ ion solution. The equilibrium of adsorption was attained after 360 minutes of exposure. According to the assessment of the kinetic models, the pseudosecond-order equation better characterized adsorption dynamics. At pH 2.0 and 3.0, the maximum removal was obtained. Compared to the Freundlich adsorption isotherm, the adsorption equilibrium values fit the Langmuir isotherm well. Using monolayer adsorption at $313 \mathrm{~K}$, the removal capacity was determined to be $4.32 \mathrm{mgg}^{-1}$.

The design flexibility, low cost, and efficiency of the biosorption process have drawn the interest of numerous researchers. To test the efficacy of groundnut shells as biosorbents for the removal of $\mathrm{Pb}^{2+}$ and $\mathrm{Cu}^{2+}$ from wastewater, Kiran et al. [49] experimented. At standard temperature, a study was led to determine the impact of $\mathrm{pH}$, contact time, and dose on the same sieve size groundnut shell. While both Langmuir and Freundlich isotherms were used to calculate the biosorption parameters, it was observed that the experimental data was better suited to the Langmuir model than to the Freundlich isotherm model. The results revealed that the maximum removal efficiency of $\mathrm{Cu}^{2+}$ and $\mathrm{Pb}^{2+}$ was $77.8 \%$ and $68.2 \%$, respectively.

Many areas across the world are affected by chromium contamination of high levels in the water, sometimes from natural sources and sometimes from manmade causes. Adsorption utilising natural materials is one of the successful methods for eliminating heavy metal ions from a variety of wastewater sources, including groundwater and surface water. Groundnut shell was used as an unconventional adsorbent in batch experiments [50] to remove $\mathrm{Cr}^{6+}$ from aqueous solutions. Groundnut shells were found to adsorb $\mathrm{Cr}^{6+}$ depending on contact time, $\mathrm{pH}$, initial concentration, and adsorbent dose. It was noted that the best situations for adsorption of $\mathrm{Cr}^{6+}$ were a 120-minute contact time, an adsorbent dosage of $2 \mathrm{gL}^{-1}$, an initial metal ion concentration of $25 \mathrm{mg} \mathrm{L}^{-1}$, and a temperature of $41.5^{\circ} \mathrm{C}$. Experimental data were also analysed by isotherm models and Langmuir found fitting well with data.

It was revealed by Bayuo et al. [51] that groundnut shells were utilised as an alternative and inexpensive adsorbent for the elimination of $\mathrm{Cr}^{6+}$ ions from water solution without any chemical or physical modification. Various solutions of $\mathrm{Cr}^{6+}$ were treated with fixed dosages of groundnut shell powder for 90 minutes to achieve equilibrium. The diphenyl carbazide indicator method was used to determine the $\mathrm{Cr}^{6+}$ concentration in the sample solutions using a UV-Visible spectrophotometer. It was observed that the groundnut shell has a substantial volume for adsorption of $\mathrm{Cr}^{6+}$ from aqueous solutions, according to the equilibrium isotherm experiments. According to the FT-IR findings, the groundnut shell may contain functional groups. These functional groups, such as amines, alcohols, and carboxylic acids, impact the biosorption of $\mathrm{Cr}^{6+}$ and are likely the process of adsorption [51].

According to a research conducted [52], natural adsorbents, for example, peanut shells and Moringa oleifera seeds may be used to remove heavy metals (lead: $\mathrm{Pb}$ ) from textile effluent. According to the results of a batch experiment, the highest removal of lead was 86.0 percent for M. oleifera, 78.0 percent for P. julifora seeds, and 72.0 for peanut shells when using different amounts of adsorbent and contact time. 
TABLE 5: Reported parameter values for pseudofirst- and pseudosecond-order kinetic models for dye adsorption on various biomass-derived adsorbents.

\begin{tabular}{|c|c|c|c|c|c|c|c|c|}
\hline \multirow{2}{*}{ Material } & \multirow{2}{*}{ Dyes } & \multicolumn{3}{|c|}{ Pseudofirst-order } & \multicolumn{3}{|c|}{ Pseudosecond-order } & \multirow{2}{*}{ Reference } \\
\hline & & $K_{1}(\mathrm{~L} / \mathrm{min})$ & $q_{e}(\mathrm{mg} / \mathrm{g})$ & $R^{2}$ & $K_{2}(\mathrm{~g} / \mathrm{mg} / \mathrm{h})$ & $q_{e}(\mathrm{mg} / \mathrm{g})$ & $R^{2}$ & \\
\hline \multirow{4}{*}{ Rice husk } & Eosin $\mathrm{Y}$ & 0.034 & 14.06 & 0.921 & 0.00537 & 32.25 & 0.999 & {$[20]$} \\
\hline & Red X & 0.027 & 5.128 & 0.863 & 0.0155 & 33.33 & 0.999 & {$[20]$} \\
\hline & Malachite green & - & - & - & 0.0329 & 21.55 & 0.999 & {$[17]$} \\
\hline & Acid yellow 17 & 0.0648 & - & 0.806 & 0.026 & - & 0.996 & [22] \\
\hline Gram seed husk & Congo red & 0.012897 & 4.0622 & 0.986 & 0.0658 & 3.8625 & 0.998 & {$[23]$} \\
\hline Coir pith & Acid yellow 99 & 0.008 & 1.023 & 0.768 & 0.042 & 4.182 & 0.999 & {$[36]$} \\
\hline \multirow{2}{*}{ Groundnut shell } & Tartrazine yellow & 8.026 & 0.234 & 0.9072 & -8.09 & 0.208 & 1 & {$[25]$} \\
\hline & Methylene blue & 0.0042 & 0.0783 & 0.3897 & 0.7790 & 2.615 & 0.9999 & {$[24]$} \\
\hline Sorghum husk & Methylene blue & 0.0048 & 0.1093 & 0.2858 & 0.6583 & 2.3980 & 0.9996 & {$[24]$} \\
\hline \multirow{2}{*}{ Canola stalks } & Acid orange 7 & 0.2211 & 2.41 & 0.8828 & 0.735 & 4.82 & 0.9998 & {$[38]$} \\
\hline & Remazol black 5 & 0.0459 & 4.50 & 0.9579 & 0.178 & 6.11 & 0.9996 & {$[38]$} \\
\hline \multirow{3}{*}{ Pine cone } & Acid black 26 & 0.23 & 7.89 & 0.49 & 0.05 & 23.70 & 1 & {$[39]$} \\
\hline & Acid green 25 & 1.03 & 9.33 & 0.94 & 0.17 & 11.27 & 1 & [39] \\
\hline & Acid blue 7 & 0.90 & 9.91 & 0.95 & 0.13 & 11.55 & 1 & [39] \\
\hline \multirow{2}{*}{ Sawdust } & Eriochrome black $\mathrm{T}$ & 0.0354 & 2.95 & 0.9985 & 0.0325 & 8.89 & 0.9998 & {$[30]$} \\
\hline & Methylene blue & 0.0175 & 17.54 & 0.9441 & 0.00067 & 14.74 & 0.9457 & {$[35]$} \\
\hline \multirow{2}{*}{ Wheat bran } & Methyl orange & 0.0134 & - & 0.97 & 0.00293 & 15.17 & 0.98 & {$[29]$} \\
\hline & Coomassie brilliant blue & 0.002073 & - & 0.469 & 0.2989 & - & 0.8396 & [27] \\
\hline
\end{tabular}

Peanut shell, M. oleifera, and P. julifora were shown to have maximal adsorption capacities of $5.6 \mathrm{mg} \mathrm{g}^{-1}, 1.7 \mathrm{mg} \mathrm{g}^{-1}$, and $1.4 \mathrm{mgg}^{-1}$ of $\mathrm{Pb}$, respectively. It was observed that the pseudosecond-order kinetic model was more accurate for peanut shell $\left(R^{2}=0.978\right), \mathrm{M}$. oleifera $\left(R^{2}=0.998\right)$, and $\mathrm{P}$. julifora $\left(R^{2}=0.995\right)$ when related to the pseudofirst-order kinetic model.

Lead and other potentially hazardous trace elements, when found in high concentrations in soil, water, and food, pose severe health risks to people across the world. According to Bayuo et al. [53] groundnut shells may effectively remove lead from water using the batch mode method. There are some evidences that functional groups such as hydroxyls and carboxylic acids may play a role in the biosorption process through Fourier transform infrared (FTIR) studies. With the help of various parameters, novel adsorbents, such as wheat bran (WB), were investigated to remove $\mathrm{Cr}^{6+}$. According to the study, it was noted that with the rise in contact time the adsorption increased and become optimum at 180 minutes. A portion of the highly hazardous $\mathrm{Cr}^{6+}$ condensed to a less lethal $\mathrm{Cr}^{3+}$ on the WB surface as $\mathrm{pH}$ rose. A solution with an initial $\mathrm{Cr}^{6+}$ concentration of $200 \mathrm{mg} \mathrm{L}^{-1}$ had a 51.0 percent removal rate at $\mathrm{pH} 2.0$. The Freundlich adsorption model characterized the isotherms of $\mathrm{Cr}^{6+}$ adsorption on wheat bran. At $\mathrm{pH} 2$, the adsorption capacity of $\mathrm{Cr}^{6+}$ was $4.53 \mathrm{mg}$ [54].

Mahmood-ul-Hassan et al. [55] investigated the adsorption of cadmium $(\mathrm{Cd})$, chromium $(\mathrm{Cr})$, and lead $(\mathrm{Pb})$ from water solution using sugarcane bagasse and wheat straw in a batch equilibrium experiment. $\mathrm{Pb}^{2+}$ was removed the most by both materials, followed by $\mathrm{Cr}^{6+}$ and $\mathrm{Cd}^{2+}$. For the adsorption process, two kinetic models were used: pseudofirst-order and pseudosecond-order. The response was consistent with the second model. The lead had the greatest Langmuir maximum adsorption capacity $\left(q_{m}\right)$ (12.8-23.3 $\mathrm{mgg}^{-1}$ sugarcane bagasse, $14.5-22.4 \mathrm{mg} \mathrm{g}^{-1}$ wheat straw), while $\mathrm{Cd}^{2+}$ had the lowest (1.5-2.2 $\mathrm{mgg}^{-1}$ sugarcane bagasse, $2.5-3.8 \mathrm{mg} \mathrm{g}^{-1}$ wheat straw). For all three adsorbents, the $q_{m}$ was in the sequence $\mathrm{Pb}>\mathrm{Cr}>\mathrm{Cd}$.

To judge the $\mathrm{Ni}^{2+}$ removal effectiveness of peanut shells using batch adsorption experiments, a research was conducted by Yildiz [56] using an ANN (artificial neural network) model. Researchers studied the impact of sorbent dose, contact time, and $\mathrm{pH}$ as well as metal concentrations and temperatures. To investigate any possible detrimental effects of the sorbent, COD (chemical oxygen demand) was determined during the experiments with different temperatures, $\mathrm{pH}$, and sorbent doses. At $\mathrm{pH} 296.21 \mathrm{mg} \mathrm{dm}^{-3}$ COD was detected, whereas at $\mathrm{pH} 754.72 \mathrm{mg} \mathrm{dm}^{-3}$ COD was discovered. As the dosage of the sorbent was increased, a substantial rise in the COD value was also observed. $0.05 \mathrm{~g}$ of sorbent produced $12.48 \mathrm{mg} \mathrm{dm}^{-3}$ of COD, whereas $1 \mathrm{~g}$ of sorbent produced $282.78 \mathrm{mg} \mathrm{dm}^{-3}$. As a result of isotherm investigations, the Freundlich isotherm $\left(R^{2}=0.97\right)$ had the greatest regression coefficient $\left(R^{2}\right)$. During kinetic experiments with changing $\mathrm{pH}$ levels, high pseudosecond- 
TABLE 6: Reported parameter values for pseudofirst- and pseudosecond-order kinetic models for heavy metal adsorption on various biomass-derived adsorbents.

\begin{tabular}{|c|c|c|c|c|c|c|c|c|}
\hline \multirow{2}{*}{ Material } & \multirow{2}{*}{ Heavy metals } & \multicolumn{3}{|c|}{ Pseudofirst-order } & \multicolumn{3}{|c|}{ Pseudosecond-order } & \multirow{2}{*}{ Reference } \\
\hline & & $K_{1}(\mathrm{~L} / \mathrm{min})$ & $q_{e}(\mathrm{mg} / \mathrm{g})$ & $R^{2}$ & $K_{2}(\mathrm{~g} / \mathrm{mg} / \mathrm{min})$ & $q_{e}(\mathrm{mg} / \mathrm{g})$ & $R^{2}$ & \\
\hline Coffee ground & $\mathrm{Cr}^{6+}$ & 0.0064 & 7.19 & 0.8752 & 0.0014 & 87.72 & 0.9996 & {$[42]$} \\
\hline \multirow{4}{*}{ Polish peats } & $\mathrm{Fe}^{3+}$ & - & - & - & 0.7722 & 11.1944 & 0.9999 & [44] \\
\hline & $\mathrm{Cr}^{6+}$ & - & - & - & 1.0068 & 3.4407 & 0.9999 & {$[44]$} \\
\hline & $\mathrm{Ni}^{2+}$ & - & - & - & 0.4721 & 0.1108 & 0.9990 & {$[44]$} \\
\hline & $\mathrm{Cu}^{2+}$ & - & - & - & 0.2378 & 0.2742 & 0.9996 & [44] \\
\hline Walnut shell & $\mathrm{Cr}^{6+}$ & 0.02553 & 30.4 & 0.937 & 0.00199 & 33.35 & 0.988 & {$[45]$} \\
\hline Almond shell & $\mathrm{Cr}^{6+}$ & 0.02826 & 14.7 & 0.914 & 0.00253 & 17.06 & 0.999 & {$[45]$} \\
\hline Coconut shell & $\mathrm{Cr}^{6+}$ & 0.02331 & 21.1 & 0.822 & 0.01986 & 21.02 & 0.988 & {$[45]$} \\
\hline \multirow{6}{*}{ Peanut shell } & $\mathrm{Cr}^{6+}$ & 0.02338 & 23.9 & 0.809 & 0.00125 & 28.70 & 0.987 & {$[45]$} \\
\hline & $\mathrm{Cr}^{6+}$ & $7 \times 10^{-3}$ & 3.29 & 0.679 & $3 \times 10^{-3}$ & 4.01 & 0.902 & {$[48]$} \\
\hline & $\mathrm{Pb}^{2+}$ & 0.415 & & 0.991 & 0.022 & & 0.986 & {$[52]$} \\
\hline & $\mathrm{Ni}^{2+}$ & 0.091 & 0.686 & 0.96 & 0.140 & 2.211 & 0.99 & [56] \\
\hline & $\mathrm{Cu}^{2+}$ & 1.804 & 7.26 & 0.977 & 0.578 & 7.48 & 0.994 & {$[58]$} \\
\hline & $\mathrm{Cr}^{3+}$ & 0.663 & 7.89 & 0.928 & 0.141 & 8.45 & 0.977 & [58] \\
\hline \multirow{2}{*}{ Wheat bran } & $\mathrm{Cd}^{2+}$ & 0.39 & 173.5 & 0.958 & 0.01 & 344.8 & 0.999 & {$[46]$} \\
\hline & $\mathrm{Pb}^{2+}$ & 0.12 & 134.9 & 0.334 & 0.01 & 555.6 & 0.999 & [46] \\
\hline \multirow{3}{*}{ Sugarcane bagasse } & $\mathrm{Cd}^{2+}$ & - & - & - & 0.088 & 1.2416 & 1.00 & [55] \\
\hline & $\mathrm{Cr}^{6+}$ & - & - & - & 0.48 & 2.3513 & 0.99 & [55] \\
\hline & $\mathrm{Pb}^{2+}$ & - & - & - & 0.0295 & 4.6253 & 0.922 & [55] \\
\hline \multirow{3}{*}{ Wheat straw } & $\mathrm{Cd}^{2+}$ & - & - & - & 0.08239 & 1.8550 & 1.00 & [55] \\
\hline & $\mathrm{Cr}^{6+}$ & - & - & - & 0.03934 & 2.8125 & 1.00 & [55] \\
\hline & $\mathrm{Pb}^{2+}$ & - & - & - & 0.0431 & 4.5085 & 1.22 & [55] \\
\hline Mixed tea waste & $\mathrm{Cr}^{6+}$ & 0.0078 & 15.78 & 0.8738 & 0.0029 & 94.34 & 0.9992 & {$[42]$} \\
\hline Coir pith & $\mathrm{Ni}^{2+}$ & 0.136 & 0.809 & 0.986 & 0.5311 & 2.066 & 0.999 & [57] \\
\hline
\end{tabular}

order kinetic model regression constants $\left(R^{2}=0.95-0.99\right)$ were observed. In order to better describe $\mathrm{Ni}^{2+}$ ion sorption on peanut shells, a pseudosecond-order kinetic model was employed since the $q_{e}$ values in the second-order kinetic equation were very closely linked to the experimental results in the first-order kinetic equation.

Coir pith was tested for its ability to remove metal impurities such as $\mathrm{Cu}, \mathrm{Ni}$, and $\mathrm{Zn}$ from water solutions [57]. The efficacy of metal removal was evaluated in batch mode under different adsorption circumstances, including $\mathrm{pH}$, the concentration of metal, and contact time. Studies on the biosorbent characteristics and SEM analysis have been carried out on the material. Lagergren pseudofirstorder and second-order models were used for kinetic modeling research. Freundlich and Langmuir isotherm models were used for equilibrium studies. A good match was discovered between all isotherms, demonstrating the effectiveness of the coir pith in heavy metal absorption. Developing adsorption techniques that take advantage of their availability and low cost might make heavy metal removal from industrial effluents more sustainable.
As a function of biomass initial concentration, initial $\mathrm{pH}$, and temperature, Witek-Krowiak et al. [58] examined the biosorption of $\mathrm{Cu}^{2+}$ and $\mathrm{Cr}^{3+}$ ions from water solutions by peanut shell biomass. Optimal sorption conditions for each metal were examined individually. There was an in-depth study of biosorption's kinetics and equilibrium. To correlate experimental data and establish kinetic parameters, pseudofirst-order and pseudosecond-order kinetic models were utilised. Two two-parameter models were used to assess the experimental data (Freundlich and Langmuir). $\mathrm{Cu}^{2+}$ and $\mathrm{Cr}^{3+}$ ion affinity and adsorption capacity of peanut shells were determined using equilibrium biosorption isotherms, with monolayer sorption capacities of $27.86 \mathrm{mg}$ $\mathrm{Cr}^{3+}$ per $1 \mathrm{~g}$ and $25.39 \mathrm{mg} \mathrm{Cu}^{2+}$ metal, respectively. Table 4 describes the reported removal efficiencies of various biomass-derived adsorbents for the adsorption of heavy metals.

2.3. Kinetic Studies. For the potential application in water pollution control, adsorption kinetics, which is controlled by adsorbate-adsorbent relations and system conditions, 
TABLE 7: Reported parameter values for Freundlich and Langmuir isotherm models for dye adsorption on various biomass-derived adsorbents.

\begin{tabular}{|c|c|c|c|c|c|c|c|c|}
\hline \multirow{2}{*}{ Material } & \multirow{2}{*}{ Dyes } & \multicolumn{3}{|c|}{ Freundlich } & \multicolumn{3}{|c|}{ Langmuir } & \multirow{2}{*}{ Reference } \\
\hline & & $K_{F}(\mathrm{~L} / \mathrm{mg})$ & $n$ & $R^{2}$ & $Q(\mathrm{mg} / \mathrm{g})$ & $K_{L}(\mathrm{~L} / \mathrm{mg})$ & $R^{2}$ & \\
\hline \multirow{8}{*}{ Wheat bran } & Remazol red F3B & 10.84 & 2.40 & 0.805 & 65.79 & 0.154 & 0.989 & {$[28]$} \\
\hline & Reactive brilliant orange $3 \mathrm{R}$ & 6.59 & 2.21 & 0.877 & 70.4 & 0.04 & 0.989 & {$[28]$} \\
\hline & Remazol black B & 2.15 & 1.49 & 0.899 & 76.3 & 0.017 & 0.982 & {$[28]$} \\
\hline & Sirius red F3B & 19.02 & 10.73 & 0.785 & 27.3 & 5.40 & 0.949 & {$[28]$} \\
\hline & Telon red BN & 18.77 & 1.91 & 0.958 & 166.6 & 0.085 & 0.981 & {$[28]$} \\
\hline & Telon yellow $4 \mathrm{R}$ & 4.02 & 1.46 & 0.890 & 96.15 & 0.03 & 0.903 & {$[28]$} \\
\hline & Coomassie & $2.5 \times 10^{-4}$ & 0.53 & 0.940 & 6.410 & 3.502 & 0.973 & {$[27]$} \\
\hline & Brilliant blue & & 1.35 & 0.987 & 59.52 & 0.088 & 0.945 & {$[27]$} \\
\hline \multirow{5}{*}{ Rice husk } & Methylene blue & $7.08 \times 10^{-13}$ & 0.205 & 0.705 & 0.266 & 1015.7 & 0.999 & {$[18]$} \\
\hline & Eosin Y & 2.11 & 1.01 & 0.906 & 58.82 & 0.025 & 0.747 & {$[20]$} \\
\hline & Red X & 17.45 & 3.95 & 0.902 & 52.63 & 0.270 & 0.999 & {$[20]$} \\
\hline & Malachite green & 4.088 & 1.38 & 0.998 & 12.16 & 0.1597 & 0.975 & {$[17]$} \\
\hline & Acid yellow 17 & 2.57 & 1.85 & 0.996 & 12.98 & 0.2286 & 0.992 & {$[22]$} \\
\hline Gram seed husk & Congo red & 0.5767 & 1.2048 & 1 & 41.66 & 0.0102 & 0.99 & {$[23]$} \\
\hline \multirow{2}{*}{ Coir pith } & Malachite green & 12.10 & 3.98 & 0.913 & 41.665 & 0.078 & 0.890 & {$[37]$} \\
\hline & Acid yellow 99 & 17.571 & 2.194 & 0.917 & 449.461 & 0.028 & 0.984 & {$[36]$} \\
\hline \multirow{2}{*}{ Groundnut shell } & Tartrazine yellow & 0.3495 & 1.031 & 0.9982 & 3.06 & 0.601 & 0.9988 & {$[25]$} \\
\hline & Methylene blue & 0.795 & 0.320 & 0.974 & 7.052 & 0.032 & 0.997 & {$[24]$} \\
\hline Sorghum husk & Methylene blue & 5.37 & 0.8634 & 0.892 & 15.385 & 0.2089 & 0.8879 & {$[24]$} \\
\hline \multirow{2}{*}{ Canola stalks } & Acid Orange 7 & 0.979 & 1.6151 & 0.9857 & 25.06 & 0.01671 & 0.9972 & {$[38]$} \\
\hline & Remazol black 5 & 2.4502 & 1.6231 & 0.9858 & 32.79 & 0.0479 & 0.9949 & {$[38]$} \\
\hline \multirow{3}{*}{ Pine cone } & Acid black 7 & 7.95 & 2.58 & 1 & 37.45 & 0.13 & 0.99 & {$[39]$} \\
\hline & Acid green 25 & 7.25 & 2.36 & 0.98 & 43.29 & 0.10 & 1 & {$[39]$} \\
\hline & Acid blue 26 & 19.47 & 3.31 & 0.98 & 62.89 & 0.23 & 1 & {$[39]$} \\
\hline \multirow{4}{*}{ Sawdust } & Eriochrome black T & 2.71 & 1.975 & 0.97 & 42.49 & 0.0269 & 0.99 & {$[30]$} \\
\hline & Direct red 23 & 9.645 & 2.56 & 0.7099 & 65.8 & 0.064 & 0.9946 & {$[33]$} \\
\hline & Crystal violet & - & - & - & 4.259 & 1.381 & 0.99 & {$[34]$} \\
\hline & Methylene blue & 14.06 & 3.645 & 0.9848 & 58.14 & 0.234 & 0.9322 & [35] \\
\hline
\end{tabular}

has been examined. Because of its relevance in the evaluation and use of adsorbents, the study of adsorption kinetics continues to attract people's interest. Additionally, the adsorbent should have a high capacity for adsorption and a fast absorption rate. The majority of adsorption research has examined adsorption kinetics using pseudofirst-order and pseudosecond-order models [59]. The kinetics of adsorption is determined by the physical and chemical characteristics of the adsorbent, as well as the mass transfer mechanism [60]. The pseudofirst-order equation which is generally expressed as [61]

$$
\operatorname{Ln}\left(q_{e}-q_{t}\right)=\ln q_{e}-k t
$$

There are two quantities of interest: the equilibrium adsorption amount $q_{e}$ and the adsorption quantity $q_{t}$ $\left(\mathrm{mgg}^{-1}\right)$, respectively, and the pseudofirst-order model's adsorption rate constant $k_{1}$. A plot of the slope and inter- cept of the line $\ln \left(q_{e}-q_{t}\right)$ in relation to time can be used to determine experimentally the parameters of kinetics, $q_{e}$, and $K_{1}$.

The pseudosecond-order equation is generally expressed as [62]

$$
\frac{\mathbb{d} q_{t}}{\mathbb{d} t}=k_{2}\left(q_{e}-q_{t}\right)^{2}
$$

where $q_{e}$ and $q_{t}$ are the sorption capacity at equilibrium and time $t\left(\mathrm{mgg}^{-1}\right)$, respectively, and $k_{2}$ is the rate constant of the pseudosecond-order sorption $\left(\mathrm{g} \mathrm{mg}^{-1} \mathrm{~h}^{-1}\right)$. The plot of $t / q_{t}$ versus $t$ describes the pseudosecond-order model, and the values of $q_{e}$ and $k_{2}$ were determined from the slopes and intercepts of the plot. Several researchers have used pseudofirst-order and pseudosecond-order models to evaluate the adsorption performance of biomass-derived 
TABLE 8: Reported parameter values for Freundlich and Langmuir isotherm models for heavy metal adsorption on various biomass-derived adsorbents.

\begin{tabular}{|c|c|c|c|c|c|c|c|c|}
\hline \multirow{2}{*}{ Material } & \multirow{2}{*}{ Heavy metals } & \multicolumn{3}{|c|}{ Freundlich } & \multicolumn{3}{|c|}{ Langmuir } & \multirow{2}{*}{ Reference } \\
\hline & & $K_{F}(\mathrm{~L} / \mathrm{mg})$ & $n$ & $R^{2}$ & $Q(\mathrm{mg} / \mathrm{g})$ & $K_{L}(\mathrm{~L} / \mathrm{mg})$ & $R^{2}$ & \\
\hline Coffee husk & $\mathrm{Cr}^{6+}$ & - & - & 0.968 & - & - & 0.9977 & {$[41]$} \\
\hline \multirow{2}{*}{ Wheat bran } & $\mathrm{Cd}^{2+}$ & 1.3 & 0.6 & 0.994 & 0.667 & 10 & 0.999 & [47] \\
\hline & $\mathrm{Pb}^{2+}$ & 1.7 & 0.6 & 0.993 & 1.667 & 20 & 0.996 & [47] \\
\hline \multirow{4}{*}{ Peanut shell } & $\mathrm{Cr}^{6+}$ & 1.25 & 3.58 & 0.9711 & 3.29 & 0.15 & 0.9867 & {$[48]$} \\
\hline & $\mathrm{Pb}^{2+}$ & 0.386 & 1.144 & 0.969 & 5.617 & 0.074 & 0.999 & {$[52]$} \\
\hline & $\mathrm{Cu}^{2+}$ & 3.09 & 2.97 & 0.936 & 25.39 & 0.022 & 0.992 & {$[58]$} \\
\hline & $\mathrm{Cr}^{3+}$ & 4.12 & 3.23 & 0.904 & 27.86 & 0.036 & 0.992 & {$[58]$} \\
\hline \multirow{2}{*}{ Groundnut shell } & $\mathrm{Cr}^{6+}$ & 0.433 & 1.840 & 0.9535 & 37.92 & 0.083 & 0.9905 & {$[50]$} \\
\hline & $\mathrm{Pb}^{2+}$ & 0.358 & 1.632 & 0.9098 & 42.64 & 0.062 & 0.9554 & [53] \\
\hline \multirow{3}{*}{ Sugarcane bagasse } & $\mathrm{Cd}^{2+}$ & - & - & - & 1.446 & 0.014 & 0.94 & {$[55]$} \\
\hline & $\mathrm{Cr}^{6+}$ & & & & 4.018 & 0.035 & 0.99 & [55] \\
\hline & $\mathrm{Pb}^{2+}$ & & & & 12.801 & 0.019 & 0.98 & [55] \\
\hline \multirow{3}{*}{ Wheat straw } & $\mathrm{Cd}^{2+}$ & - & - & - & 2.528 & 0.032 & 0.99 & {$[55]$} \\
\hline & $\mathrm{Cr}^{6+}$ & & & & 5.066 & 0.082 & 0.99 & {$[55]$} \\
\hline & $\mathrm{Pb}^{2+}$ & & & & 14.513 & 0.034 & 0.99 & [55] \\
\hline \multirow{3}{*}{ Coir pith } & $\mathrm{Ni}^{2+}$ & 1.09 & 2.67 & 0.98 & 4.17 & 0.21 & 0.99 & [57] \\
\hline & $\mathrm{Cu}^{2+}$ & 0.69 & 3.07 & 0.98 & 2.06 & 0.33 & 0.99 & [57] \\
\hline & $\mathrm{Zn}^{2+}$ & 1.71 & 2.63 & 0.98 & 5.49 & 0.30 & 0.99 & [57] \\
\hline
\end{tabular}

adsorbents to different dyes and heavy metals. Tables 5 and 6 show reported kinetic model parameter values for dye and heavy metal adsorption on various biomass-derived adsorbents.

2.4. Adsorption Isotherms. The adsorption isotherm is a useful tool for modeling adsorption behavior. It explains the nature and mechanism of adsorption by describing how the adsorbate interacts with the adsorbent. When comparing the adsorption capacities of different adsorbents, it is critical to analyse the isotherm data. Freundlich and Langmuir's isotherms are used to analyse experimental data and to estimate the quantity and degree of adsorption favorability in adsorption investigations. Consider a monolayer or multilayer surface phase [63]. It is generally known that there are two types of adsorption isotherms: the Freundlich and the Langmuir. The Langmuir isotherm assumes monolayer adsorption onto a surface with a finite number of adsorption sites and homogeneous adsorption methods, with no adsorbate transmigration in the surface plane [64]. The Freundlich isotherm model assumes heterogeneous surface energies, with the energy component in the Langmuir equation varying as a function of the surface coverage [65]. The Langmuir isotherm is derived by assuming that there are a finite number of adsorption sites and that adsorption is reversible.

The Langmuir adsorption isotherm model is expressed as [66]

$$
q_{e}=\frac{q_{m} K_{L} C_{e}}{1+K_{L} C_{e}}
$$

In this equation, $q_{e}$ is the quantity of dye adsorbed at equilibrium time (in $\mathrm{mg} \mathrm{g}^{-1}$ ), $C_{e}$ is the equilibrium concentration of dye in solution (in $\mathrm{mg} \mathrm{L}^{-1}$ ), $q_{m}$ is the maximum adsorption capacity (in $\mathrm{mg} \mathrm{g}^{-1}$ ), and $K_{L}$ is the Langmuir isotherm constant $\left(\mathrm{L} \mathrm{mg}^{-1}\right)$.

The Freundlich adsorption isotherm model is expressed as [67]

$$
q_{e}=K_{F} C_{e}^{N}
$$

where $C_{e}$ is the equilibrium dye concentration in solution $\left(\mathrm{mg} \mathrm{L}^{-1}\right), q_{e}$ is the quantity of adsorbate at equilibrium time $\left(\mathrm{mg} \mathrm{g}^{-1}\right), K_{F}$ is the capacity of the adsorbent, and $N$ is the intensity of adsorption constant for Freundlich's equation. The adsorption efficiency of biomass-derived adsorbents to dyes and heavy metals has been studied by several researchers using Langmuir and Freundlich models. Tables 7 and 8 show reported dye and heavy metal adsorption isotherm parameter values onto several biomassderived adsorbents.

\section{Conclusion and Future Prospective}

The use of biomass-derived adsorbents for the removal of dyes and heavy metals from wastewater is discussed in this study. It is based on a significant number of relevant research papers that have been published in the last ten years. Biomass-derived adsorbents are abundantly available and are of specific significance, easy to dispose of, and easy application. The comparisons of different adsorbents are 
also discussed by their removal efficiencies and adsorption capacities. The adsorption rate is an essential consideration when selecting an adsorbent since the adsorbent should have a high adsorption capacity and a rapid adsorption rate. For this purpose, the data was also collected for two main kinetic models. An adsorption isotherm is a useful tool for modeling adsorption behavior. In adsorption studies, Langmuir and Freundlich's isotherms are used to fit the experimental data, and how to determine the amount and degree of adsorption favorability was also discussed. In general, this study emphasizes the benefits of utilising adsorbents generated from biomass for the removal of dyes and heavy metals. As shown by the study of the literature, the majority of adsorption studies are carried out on a batch scale and have not been fully developed for the treatment of real industrial effluents at pilot and industrial scales. Additionally, the actual industrial effluents were contaminated with a variety of contaminants, necessitating extensive research into the selectivity of adsorbents in actual effluents. More studies are required to evaluate the adsorption of these adsorbents on real wastewater treatment plants and pilot scales as well as the assessment of challenges in the application of these biosorbents on large-scale wastewater treatments.

\section{Data Availability}

The data used to support the findings of this study are available from the corresponding author upon request.

\section{Conflicts of Interest}

The authors declare that they have no known competing financial interests or personal relationships that could have appeared to influence the work reported in this paper.

\section{References}

[1] L. V. A. Gurgel, O. K. Júnior, R. P. . F. Gil, and L. F. Gil, "Adsorption of $\mathrm{Cu}(\mathrm{II}), \mathrm{Cd}(\mathrm{II})$, and $\mathrm{Pb}$ (II) from aqueous single metal solutions by cellulose and mercerized cellulose chemically modified with succinic anhydride," Bioresource Technology, vol. 99, no. 8, pp. 3077-3083, 2008.

[2] Q. Manzoor, R. Nadeem, M. Iqbal, R. Saeed, and T. M. Ansari, "Organic acids pretreatment effect on Rosa bourbonia phytobiomass for removal of $\mathrm{Pb}(\mathrm{II})$ and $\mathrm{Cu}(\mathrm{II})$ from aqueous media," Bioresource Technology, vol. 132, pp. 446-452, 2013.

[3] P. S. Kumar, S. Ramalingam, V. Sathyaselvabala, S. D. Kirupha, A. Murugesan, and S. Sivanesan, "Removal of cadmium(II) from aqueous solution by agricultural waste cashew nut shell," Korean Journal of Chemical Engineering, vol. 29, no. 6, pp. 756-768, 2012.

[4] T. A. Johnson, N. Jain, H. C. Joshi, and S. Prasad, “Agricultural and agro-processing wastes as low cost adsorbents for metal removal from wastewater: a review," Journal of Scientific and Industrial Research (JSIR), vol. 67, no. 9, pp. 647-658, 2008.

[5] L. B. Escudero, P. Y. Quintas, R. G. Wuilloud, and G. L. Dotto, "Biosorption of metals and metalloids," in Green Adsorbents for Pollutant Removal, Springer, 2018.

[6] ZDHC, ZDHC (zero discharge of hazardous chemicals) Wastewater Guidelines Version 1.1, 2019.
[7] T. Robinson, B. Chandran, and P. Nigam, "Removal of dyes from a synthetic textile dye effluent by biosorption on apple pomace and wheat straw," Water Research, vol. 36, no. 11, pp. 2824-2830, 2002.

[8] A. Mittal, L. Kurup, and J. Mittal, "Freundlich and Langmuir adsorption isotherms and kinetics for the removal of Tartrazine from aqueous solutions using hen feathers," Journal of Hazardous Materials, vol. 146, no. 1-2, pp. 243-248, 2007.

[9] S. Srivastava, R. Sinha, and D. Roy, "Toxicological effects of malachite green," Aquatic Toxicology, vol. 66, no. 3, pp. 319329, 2004.

[10] G. McKay, "Waste color removal from textile effluents," American Dyestuff Reporter, vol. 68, no. 4, p. 29, 1979.

[11] V. J. P. Poots, G. Mckay, and J. J. Healy, "The removal of acid dye from effluent using natural adsorbents-I peat," Water Research, vol. 10, no. 12, pp. 1061-1066, 1976.

[12] A. Bhatnagar, M. Sillanpää, and A. Witek-Krowiak, "Agricultural waste peels as versatile biomass for water purification - a review," Chemical Engineering Journal, vol. 270, pp. 244-271, 2015.

[13] S. Babel and T. A. Kurniawan, "Various treatment technologies to remove arsenic and mercury from contaminated groundwater: an overview," Southeast Asian Water Environ, vol. 1, 2005.

[14] V. K. Gupta, S. Agarwal, and T. A. Saleh, "Synthesis and characterization of alumina-coated carbon nanotubes and their application for lead removal," Journal of Hazardous Materials, vol. 185, no. 1, pp. 17-23, 2011.

[15] A. G. Varghese, S. A. Paul, and M. S. Latha, "Remediation of heavy metals and dyes from wastewater using cellulose-based adsorbents," Environmental Chemistry Letters, vol. 17, no. 2, pp. 867-877, 2019.

[16] F. S. Abbas, "Dyes removal from wastewater using agricultural waste," Advances in Environmental Biology, vol. 7, no. 6, pp. 1019-1026, 2013.

[17] S. Chowdhury, R. Mishra, P. Saha, and P. Kushwaha, "Adsorption thermodynamics, kinetics and isosteric heat of adsorption of malachite green onto chemically modified rice husk," Desalination, vol. 265, no. 1-3, pp. 159-168, 2011.

[18] P. Sharma, R. Kaur, C. Baskar, and W. J. Chung, "Removal of methylene blue from aqueous waste using rice husk and rice husk ash,” Desalination, vol. 259, no. 1-3, pp. 249-257, 2010.

[19] V. M. Sivakumar, M. Thirumarimurugan, A. M. Xavier, A. Sivalingam, and T. Kannadasan, "Colour removal of direct red dye effluent by adsorption process using rice husk," International Journal of Bioscience, Biochemistry and Bioinformatics, vol. 2, no. 6, pp. 377-380, 2012.

[20] S. F. Shafeii Darabi, N. Bahramifar, and M. A. Khalilzadeh, "Equilibrium, thermodynamic and kinetics studies on adsorption of eosin Y and red X-GRL from aqueous solution by treated rice husk," Journal of Applied Research in Water and Wastewater, vol. 5, no. 1, pp. 392-398, 2018.

[21] S. Saroj, S. V. Singh, and D. Mohan, "Removal of colour (direct blue 199) from carpet industry wastewater using different biosorbents (maize cob, citrus peel and rice husk)," Arabian Journal for Science and Engineering, vol. 40, no. 6, pp. 1553-1564, 2015.

[22] C. Patil, G. M. Ratnamala, S. T. Channamallayya, and K. Belagavi, "Adsorption studies for removal of acid yellow 17 using activated rice husk," International Research Journal of Engineering and Technology, vol. 2, no. 5, pp. 769-774, 2015. 
[23] M. C. Somasekhara Reddy, V. Nirmala, and C. Ashwini, "Bengal gram seed husk as an adsorbent for the removal of dye from aqueous solutions - batch studies," Arabian Journal of Chemistry, vol. 10, pp. S2554-S2566, 2017.

[24] A. M. Hammari, H. Abubakar, M. I. Misau, and U. O. A. U. D. Hamza, "Adsorption equilibrium and kinetic studies of methylene blue dye using groundnut Shell and sorghum husk biosorbent," Journal of Environmental Bioremediation and Toxicology, vol. 3, no. 2, pp. 32-39, 2020.

[25] A. K. Asiagwu, "Removal of tartrazine yellow dye from aqueous solution using groundnut shell as biomass: kinetic approach," International Journal of Engineering Research, vol. V7, no. 5, 2018.

[26] M. B. Ibrahim, A. M. Ibrahim, M. A. Haruna, and M. S. Yaro, "Removal of Congo red dye from aqueous solution using sugarcane bagasse and bambara groundnut shell," ChemSearch Journal, vol. 4, no. 1, pp. 22-28, 2013.

[27] S. Ata, M. Imran Din, A. Rasool, I. Qasim, and I. Ul Mohsin, "Equilibrium, thermodynamics, and kinetic sorption studies for the removal of coomassie brilliant blue on wheat bran as a low-cost adsorbent," Journal of Analytical Methods in Chemistry, vol. 2012, Article ID 405980, 8 pages, 2012.

[28] P. Taylor, M. T. Sulak, and H. C. Yatmaz, "Removal of textile dyes from aqueous solutions with eco-friendly biosorbent," Desalination and Water Treatment, vol. 37, pp. 169-177, 2012.

[29] A. S. Alzaydien, "Adsorption behavior of methyl orange onto wheat bran: Role of surface and $\mathrm{pH}$," Oriental Journal of Chemistry, vol. 31, no. 2, pp. 643-651, 2015.

[30] S. Akhouairi and H. Ouachtak, "Natural sawdust as adsorbent for the eriochrome black $\mathrm{T}$ dye removal from aqueous solution tres tres tres tres tres interessant.pdf," Water, Air, \& Soil Pollution, vol. 230, no. 8, pp. 1-15, 2019.

[31] M. Shafiqul Alam, "Removal of Congo Red Dye from industrial wastewater by untreated sawdust," American Journal of Environmental Protection, vol. 4, no. 5, p. 207, 2015.

[32] R. Karthik, R. Muthezhilan, A. Jaffar Hussain, K. Ramalingam, and V. Rekha, "Effective removal of methylene blue dye from water using three different low-cost adsorbents," Desalination and Water Treatment, vol. 57, no. 23, pp. 10626-10631, 2016.

[33] A. Hebeish, M. A. Ramadan, E. Abdel-Halim, and A. AboOkeil, "An effective adsorbent based on sawdust for removal of direct dye from aqueous solutions," Clean Technologies and Environmental Policy, vol. 13, no. 5, pp. 713-718, 2011.

[34] S. D. Khattri and M. K. Singh, "Use of Sagaun sawdust as an adsorbent for the removal of crystal violet dye from simulated wastewater," Environmental Progress \& Sustainable Energy, vol. 31, no. 3, pp. 435-442, 2012.

[35] S. Suganya, P. Senthil Kumar, A. Saravanan, P. Sundar Rajan, and C. Ravikumar, "Computation of adsorption parameters for the removal of dye from wastewater by microwave assisted sawdust: theoretical and experimental analysis," Environmental Toxicology and Pharmacology, vol. 50, pp. 45-57, 2017.

[36] M. M. R. Khan, M. Ray, and A. K. Guha, "Mechanistic studies on the binding of acid yellow 99 on coir pith," Bioresource Technology, vol. 102, no. 3, pp. 2394-2399, 2011.

[37] V. R. S. Cheela, D. V. Padma, and G. S. Kumar, "Studies on the removal of malachite green using Indian activated coir pith," $i$ Manager's Journal on Future Engineering and Technology, vol. 10, no. 1, pp. 18-26, 2014.

[38] Y. Hamzeh, A. Ashori, E. Azadeh, and A. Abdulkhani, "Removal of Acid Orange 7 and Remazol Black 5 reactive dyes from aqueous solutions using a novel biosorbent," Materials Science and Engineering: C, vol. 32, no. 6, pp. 1394-1400, 2012.

[39] N. M. Mahmoodi, B. Hayati, M. Arami, and C. Lan, “Adsorption of textile dyes on pine cone from colored wastewater: kinetic, equilibrium and thermodynamic studies," Desalination, vol. 268, no. 1-3, pp. 117-125, 2011.

[40] M. S. Alam, R. Khanom, and M. A. Rahman, "Removal of Congo Red dye from industrial wastewater by untreated sawdust," American Journal of Environmental Protection, vol. 4, no. 5, p. 207, 2015.

[41] D. Berihun, "Removal of chromium from industrial wastewater by adsorption using coffee husk," Journal of Materials Science and Engineering, vol. 6, no. 2, pp. 6-11, 2017.

[42] W. Cherdchoo, S. Nithettham, and J. Charoenpanich, "Removal of $\mathrm{Cr}(\mathrm{VI})$ from synthetic wastewater by adsorption onto coffee ground and mixed waste tea," Chemosphere, vol. 221, pp. 758-767, 2019.

[43] Z. Babazad, F. Kaveh, M. Ebadi, R. Z. Mehrabian, and M. H. Juibari, "Efficient removal of lead and arsenic using macromolecule-carbonized rice husks," Heliyon, vol. 7, no. 3, 2021.

[44] S. Charazińska, P. Lochyński, and E. Burszta-Adamiak, "Removal of heavy metal ions form acidic electrolyte for stainless steel electropolishing via adsorption using Polish peats," Journal of Water Process Engineering, vol. 42, 2021.

[45] I. Loulidi, F. Boukhlifi, M. Ouchabi et al., "Adsorptive removal of chromium (VI) using walnut shell, almond shell, coconut shell and peanut shell," Research Journal of Chemistry and Environment, vol. 23, no. 12, pp. 25-32, 2019.

[46] F. Ogata, M. Kangawa, H. Tominaga et al., "Study of adsorption mechanism of heavy metals onto waste biomass (wheat bran)," Journal of Oleo Science, vol. 62, no. 11, pp. 949-953, 2013.

[47] F. Ogata, M. Kangawa, Y. Iwata, A. Ueda, Y. Tanaka, and N. Kawasaki, "A study on the adsorption of heavy metals by using raw wheat bran bioadsorbent in aqueous solution phase," Chemical \& Pharmaceutical Bulletin, vol. 62, no. 3, pp. 247-253, 2014.

[48] M. Ilyas, A. Ahmad, and M. Saeed, "Removal of Cr (VI) from aqueous solutions using peanut shell as adsorbent," Journal of the Chemical Society of Pakistan, vol. 35, no. 3, pp. 760-768, 2013.

[49] B. Kiran, S. Srikantaswamy, H. Pallavi, and V. Manoj, “A study on utilization of groundnut shell as biosorbant for heavymetals removal," JECET : Journal of Environmental Science, Computer Science and Engineering \& Technology, vol. 2, no. 1, pp. 173186, 2013.

[50] J. Bayuo, K. B. Pelig-Ba, and M. A. Abukari, "Adsorptive removal of chromium(VI) from aqueous solution unto groundnut shell," Applied Water Science, vol. 9, no. 4, pp. 111, 2019.

[51] J. Bayuo, M. A. Abukari, and K. B. Pelig-ba, "Equilibrium isotherm studies for the sorption of hexavalent chromium (VI) onto groundnut shell," IOSR Journal of Applied Chemistry (IOSR-JAC), vol. 11, no. 12, pp. 40-46, 2018.

[52] A. K. Gautam, N. Markandeya, B. Singh, S. P. Shukla, and D. Mohan, "Lead removal efficiency of various natural adsorbents (Moringa oleifera, Prosopis juliflora, peanut shell) from textile wastewater," SN Applied Sciences, vol. 2, no. 2, pp. 111, 2020. 
[53] J. Bayuo, K. B. Pelig-ba, and M. A. Abukari, "Isotherm modeling of lead ( II ) adsorption from aqueous solution using groundnut shell as a low-cost adsorbent," IOSR Journal of Applied Chemistry (IOSR-JAC), vol. 11, no. 11, pp. 18-23, 2018.

[54] K. Kaya, E. Pehlivan, C. Schmidt, and M. Bahadir, "Use of modified wheat bran for the removal of chromium(VI) from aqueous solutions," Food Chemistry, vol. 158, pp. 112-117, 2014.

[55] M. Mahmood-ul-Hassan, V. Suthar, E. Rafique, R. Ahmad, and M. Yasin, "Kinetics of cadmium, chromium, and lead sorption onto chemically modified sugarcane bagasse and wheat straw," Environmental Monitoring and Assessment, vol. 187, no. 7, 2015.

[56] S. Yildiz, "Artificial neural network approach for modeling of $\mathrm{Ni}(\mathrm{II})$ adsorption from aqueous solution by peanut shell," Ecological Chemistry and Engineering S, vol. 25, no. 4, pp. 581-604, 2018.

[57] K. Swarnalatha and S. Ayoob, "Adsorption studies on coir pith for heavy metal removal," International Journal of Sustainable Engineering, vol. 9, no. 4, pp. 259-265, 2016.

[58] A. Witek-Krowiak, R. G. Szafran, and S. Modelski, "Biosorption of heavy metals from aqueous solutions onto peanut shell as a low-cost biosorbent," Desalination, vol. 265, no. 1-3, pp. 126-134, 2011.

[59] M. U. Javaid, K. Ali, M. U. Qayyum, A. Raza, M. Gul, and Z. Ali, "Utilization of fly and coarse ash for removal of heavy metal ions from contaminated water," Acta Scientific Agriculture, vol. 5, no. 8, pp. 18-24, 2021.

[60] S. Wang, Y. Boyjoo, A. Choueib, and Z. H. Zhu, "Removal of dyes from aqueous solution using fly ash and red mud," Water Research, vol. 39, no. 1, pp. 129-138, 2005.

[61] S. K. Lagergren, "About the theory of so-called adsorption of soluble substances," Sven. Vetenskapsakad. Handingarl, vol. 24, pp. 1-39, 1898.

[62] Y. S. Ho, G. McKay, D. A. J. Wase, and C. F. Forster, "Study of the sorption of divalent metal ions on to peat," Adsorption Science and Technology, vol. 18, no. 7, pp. 639-650, 2000.

[63] M. A. M. Salleh, D. K. Mahmoud, W. A. W. A. Karim, and A. Idris, "Cationic and anionic dye adsorption by agricultural solid wastes: a comprehensive review," Desalination, vol. 280, no. 1-3, pp. 1-13, 2011.

[64] K. Fytianos, E. Voudrias, and E. Kokkalis, "Sorption-desorption behaviour of 2, 4-dichlorophenol by marine sediments," Chemosphere, vol. 40, no. 1, pp. 3-6, 2000.

[65] T. W. Weber and R. K. Chakravorti, "Pore and solid diffusion models for fixed-bed adsorbers," AICHE Journal, vol. 20, no. 2, pp. 228-238, 1974.

[66] I. Langmuir, "The constitution and fundamental properties of solids and liquids. Part I. Solids," Journal of the American Chemical Society, vol. 38, no. 11, pp. 2221-2295, 1916.

[67] H. Freundlich, "Uber die adsorption in lösungen," Zeitschrift für Physikalische Chemie, vol. 57, no. 1, pp. 385-470, 1907. 